Expense account
Japan's offer to pay
for trip unnerves
$\begin{aligned} & \text { Nobel officials } \\ & \text { p676 }\end{aligned}$

\title{
Bioweapons treaty in disarray as US blocks plans for verification
}

\section{Declan Butler, Paris}

The United States is facing bitter recriminations over its tactics at an international meeting on biological weapons in Geneva. The talks to review the 1972 Biological Weapons Convention (BWC) collapsed on 7 December without agreement.

A unanimous vote to adjourn the conference until next November followed a move by the United States to block new means for verifying compliance with the BWC's terms.

As the meeting finished, negotiators from European Union (EU) states openly condemned the US tactics - echoing the deep divisions that characterized international conferences on topics such as global warming before the 11 September terrorist attacks. The EU delegation was sufficiently annoyed that it refused to sit with its US allies during the closing session of the meeting.

Critics of the Bush administration say it has committed a sizeable diplomatic blunder, alienating its closest allies and also failing in its bid to stop the BWC parties from attempting fresh negotiations for a verification protocol in the future. But the administration believes that it succeeded in postponing the difficult issue of international agreement on bioweapons, without sustaining any real political damage.

The adjournment leaves the BWC in disarray. But some observers say that the enforced 'cooling off' period, together with the galvanization of opposition at the meeting to the Bush administration's position, may ultimately result in greater international impetus towards an expanded BWC agreement.

Less than two hours before the scheduled end of the conference, the United States tabled a demand that other countries were always going to reject: the formal abolition of a remit requiring parties to the $\mathrm{BWC}$ to agree on legally binding measures to ensure compliance. In July, the United States had said that it would veto a draft protocol allowing for inspections of facilities, arguing that this would not catch bioweapons proliferators, and would open up US biodefence establishments and biotechnology companies to espionage (see Nature 412, 365; 2001).

From the outset, it was recognized that

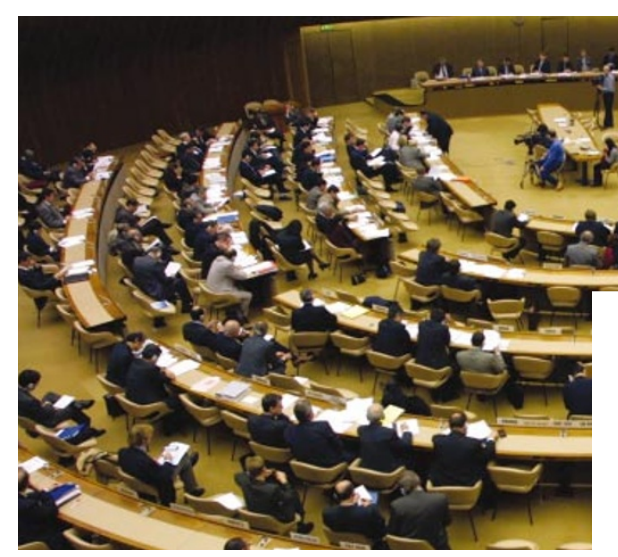

Fighting talk: under-secretary of state John Bolton (right) raises US concerns in Geneva.

discussion of this remit at the meeting would probably result in the breakdown of the talks, which required unanimous consent to proceed. So parties representing the BWC's 144 signatory states had tacitly agreed to ignore the issue, negotiators say.

Instead, the talks sought consensus on two other issues. One was the nature of future BWC review meetings. To get around US opposition to formal discussion of verification protocols, the EU proposed ad hoc meetings alongside the five-year review conferences.

The other was the question of how to deal with signatories suspected of running covert, offensive biological weapons programmes. Initially, the United States demanded that five named states - including Iran and Iraq "terminate their offensive biological weapons programmes and fully comply with their obligations". This irked some parties because it ignored eight other nations - including Russia, China and Israel — that the United States acknowledges as having similar programmes.

On the last morning of the meeting, the United States offered a concession, asking instead that parties express "grave concern that compliance... has been subject to doubt in certain cases". This was expected to win the meeting's support, negotiators say.

But with agreement in sight, the United States abandoned its position, saying that it would only agree to the compromise if the 